\title{
A Revision of the Geophilous Species of Peperomia, with some additional Notes on their Morphology and Seedling Structure.
}

BY

\author{
ARTHUR W. HILL, M.A. \\ Fellow and Dean of King's College, Cambridge, University Lechurer in Botany.
}

With Plate XV.

THE discovery of the seedlings of certain of the geophilous Peperomias, 1 which have been described in the last volume of the Annals of Botany $^{1}$, has necessitated a re-examination of all the bulbous species of the genus. The confusion existing between the Peruvian and Mexican representatives has been referred to, and some attempt has already been made to disentangle and distinguish the various species ${ }^{2}$. As it was impossible to clear up the various points of systematic interest from the material in our British herbaria, a visit has been paid to the herbaria at Geneva for this purpose.

I must here express my thanks to M. C. de Candolle for his kindness in allowing me to work in his Herbarium, where, in addition to his own collection, I was able to see all the material from the Berlin Herbarium, including the plants recently collected by Weberbauer and Fiebrig. $\mathrm{He}$ has further very generously allowed me to describe the new species, and to write this account of the geophilous forms, although he himself is at work on a new monograph of the genus. The Boissier and De Lessert Herbaria were also visited, and I am much indebted for the kindness and attention which I received there. I must also add a word of thanks to Dr. Stapf for the kind help he has given me in connexion with this revision. As the principal result of this work, a classification of the geophilous Peperomias is put forward on a new basis, namely, on the character of the underground tuber, which affords not only a very ready method of recognizing the plants from particular regions, but also appears to indicate, to a certain extent, the natural relationships of the various species.

The final separation of the species is effected mainly by the characters of the fruits, as in Dahlstedt's monograph ${ }^{3}$, and in some cases the venation,

\footnotetext{
1 Hill in Ann. Bot., vol. xx, p. 395. $\quad 2$ Ibid., pp. 396-8.
}

3 Dahlst. in Kong. Svenska Vet. Akad. Hand. Bd. 33, No. 2, 1900.

[Annals of Botany, Vol. XXI. No. LXXXII. Apri1, 1907.] 
texture, and internal structure of the leaf are of great value. A few additional points of biological interest, with regard both to the seedling structure and to the development of the bulb or rhizome, have come to light during this investigation, an account of which will be given below. Seven new species are described in the course of this paper, and the descriptions of most of the known species have undergone considerable emendations.

\section{HISTORY.}

The first of the bulbous species to be described was the Peperomia umbilicata of Ruiz and Pavon ${ }^{1}$ in 1798 , from the neighbourhood of Lima in Peru; it is a well-marked form, which does not appear to have been brought to Europe since Pavon's time. The bulb or tuber is more or less placentiform in shape, the roots spring from the sides and base, whilst the upper part is bare and crowned by the rosette of radical leaves. The next specimens to arrive in Europe were those collected by Humboldt in Mexico, which are figured and referred by Kunth ${ }^{2}$ in 1815 to the same species as Pavon's Peruvian plant. In the figure the roots appear to emerge more or less from a point on the upper surface of the bulb, which is described as being about the size of a pea.

In other respects the descriptions of the two plants agree, and since ripe fruits were not obtained, and the characters of bulb and leaf were not very clearly noted, it is scarcely surprising that these two plants should have been considered to belong to the same species. Since this time many geophilous forms have been collected both in Mexico and in Peru, and all those with a distinct bulb have been referred to $P$. umbilicata, apparently without any critical examination of the plants having been undertaken.

Thus in the Prodromus, at least four well-marked and easily separable species are included under $P$. umbilicata, R. and P., and even Dahlstedt, though he has removed certain plants from this collection to form his new species, $P$. peruviana (Miq.), Dahlst. ${ }^{3}$, has failed to separate the Peruvian from the Mexican forms, with which they have been so long confused. Specimens belonging to two distinct species are also included under $P$.parvifolia, C. DC., both by De Candolle and Dahlstedt ${ }^{4}$. It is owing

${ }^{1}$ Ruiz and Pavon, Fl. Peruv., i, p. 30, T. 45, Fig. 6.

${ }^{2}$ H. B. and K., Nov. Gen., i, p. 59, T. I5, Fig. I.

${ }^{3}$ Dahlst., l. c., p. $3^{2}$.

${ }^{4}$ DC. Prod., XVI, i, p. 393. Dahlst., 1.c., p. 30. P. parvifolia, C. DC. was described in Seeman's Journal of Botany of I 866 , p. I 33 , from Pentland's specimen (from I 2,850 feet) at Kew and from a Pavon specimen in the Boissier Herbarium. In the Prodromus in 1869, p. 393, Mandon's plant No. II 23 is added to the two just mentioned, and the diagnosis is amplified by a description of the ovary; the spikes also are said to be dense-flowered. The Pavon plant, which appears to be similar to Mandon No. I I 23, has no ripe fruits, but was probably the plant on which the original description was based, for Pentland's plant is without doubt a specimen of $P$. perivviana, Dahlst. 
to this confusion that the classification of the geophilous Peperomias has been so difficult, and it was in the hope of arriving at a solution of the problem that this research was undertaken.

\section{General Morphology.}

The correlation between the pseudo-monocotyledonous method of germination and the geophilous habit in these Peperomias has already been discussed $^{1}$, and some account of the underground tuberous portion of these plants has been given, but it will be useful to refer briefly to the various types of bulb or rhizome which are found among these species at this point, on account of their value for purposes of classification.

There appear to be four well-marked types of underground stem, which will be distinguished by the names of the prominent species. In the simplest or parvifolia type there is a simple, smooth, more or less spherical corm, with a basal tuft of roots and an apical crown of leaves ${ }^{2}$. In the case of old corms, owing to the division of the growing-point, there may be two or three rosettes of leaves. The central cylinder runs vertically through the corm from the stem-apex to the point of emergence of the roots, and the general appearance and structure very closely resembles that of a crocus corm. To this type belong four Peruvian and Bolivian species, $P$. parvifolia, $P$. verruculosa, $P$. mimuta, and $P$. cyclaminoides.

To the next or umbilicata type belong those species in which the underground stem is a hypocotyledonary tuber, as in the preceding group, but the roots arise irregularly from the sides and base ${ }^{3}$. In the seedling ${ }^{4}$ the primary root is vertical, but it is soon replaced by adventitious roots which spring from the sides of the little tubers ${ }^{5}$. The three species from South America, which must be included here, differ somewhat from each other. In P. umbilicata, R. and P., collected by Pavon, the roots arise in a somewhat regular ring round the middle of the spherical tuber, leaving the upper part free, and having a few roots scattered over the base; whilst in $P$. peruivina and $P$. falsa the roots are scattered in an indefinite manner over the sides and base of the tuber, which is often warted and irregular in outline ${ }^{6}$.

The third or campylotropa type is of particular interest, and an account, with figures of the development of this peculiar form of tuber, has been given in the previous paper ${ }^{7}$. Some nine or ten species belong to this group and, with one exception, are all natives of Mexico and Central America. In the paper referred to, the opinion was expressed that this form of tuber was entirely confined to the Mexican region, but from an

1 Hill, l. c., p. 397 .

${ }^{3}$ Cf. Hill, l. c., Pl. XXIX, Figs. I and 2.

5 l. c., Pl. XXIX, Figs. II and $I_{5}$.

7 l. c., pp. 407-4Io, Pl. XXX, Figs. 532-39.

${ }^{2}$ Cf. Hill, 1. c., P1. XXIX, Fig. 27.

${ }^{4}$ 1. c., Pl. XXIX, Figs. 5-IO.

${ }^{6}$ l. c., Pl. XXIX, Fig. I. 
examination of Gaudichaud's specimens from the country round Limawith which one of Weberbauer's ${ }^{1}$ plants agrees - it is clear that there is at least one South American example in which the roots have been carried round to the upper surface of the tuber ${ }^{2}$. This species, which I have named $P$. Gaudichaudii, has a somewhat different arrangement of its roots in old tubers to that seen in the Mexican examples. In the latter case the roots arise in a single tuft on one side of the stem-apex ${ }^{3}$, whilst in the former (cf. Pl. XV, Figs. 3 and 4), although the bulb develops at first as in $P$. pedicellata, yet as it gets older the point of origin of the roots is gradually extended round the apex until the leaf rosette is enclosed by a ring of roots. These form a mass densely felted together by root hairs, which spread over and obscure the small bulb below, so that the leaves and inflorescences appear to spring from a dense mass of roots, and the bulb may be easily overlooked. Owing to the sharp curving of the central cylinder of the hypocotyl in the young tuber, by means of which the primary root is carried round to the upper surface ${ }^{4}$, the name campylotropa has been given to Kunth's P. umbilicata from Mexico ${ }^{5}$, which is perhaps the best known and most typical species of this group.

The mode of development of the underground stem in the fourth or rhizomatous type is known only in the case of $P$. macrandra ${ }^{6}$, and it is possible that the three or four species, which can be placed in such a group, are not really very closely allied. $P$. mexicana occupies an intermediate position between the third and fourth types, since in the young plant there is a small warted tuber with a basal root, which appears to be carried round slowly to the upper surface; then by the continued growth of the stem-apex a short rhizome is produced, which may produce adventitious roots, but retains the old irregular tuber at its base (Pl. XV, Fig. 5) ${ }^{7}$. The effect in this case is, on a very small scale, like that produced by the rhizome of Cyclamen europaeum ${ }^{8}$.

The typical rhizome of the group is seen in $P$. macrandra ${ }^{9}$, where it occurs as a blackish-green, branched organ, creeping probably near the surface of the ground. It is some three or more $\mathrm{cm}$. in length, with more or less erect branches about I $\mathrm{cm}$. long, provided with adventitious roots, and marked by large leaf-scars. The mode of development of the two other species placed in this group is at present unknown. $P$. monticola appears at first to have a campylotropous bulb, which then develops

1 Weberbauer, No. 1632 Amancäes, in montibus prope Lima 2-800 m.

${ }^{2}$ Hill in Ann. Bot. xx, footnote (I), p. 396 .

${ }^{3}$ Ibid., 1. c., Pl. XXX, Fig. 38.

4 Ibid., 1. c., Pl. XXX, Fig. 40.

${ }^{5}$ Kunth in H. B. and K., Nov. Gen., i, p. 59 ; 1. c., p. 407.

6 C. DC., in Ann. du Conserv. du Jard. Bot. Genève, 1878 , p. 276.

7 Hill, l. c., P. 4II, Pl. XXX, Figs. 42, 44, 45.

${ }^{8}$ Hildebrand, Die Gattung Cyclamen, p. 22, \&c.

9 Hill, l. c., p. $4^{\text {I } 2, ~ P l . ~ X X X, ~ F i g . ~} 4^{6 .}$ 
into a short, irregularly tuberous rhizome; and P. rupiceda, C. DC., a new species brought by Weberbauer from Peru, has also a short, more or less horizontal, tuberous rhizome some $2 \mathrm{~cm}$. long, provided with adventitious roots from all over the surface, and narrowed to the erect stem-apex.

It is possible that $P$. puberula, Baker ${ }^{1}$, and some other species with well-developed rhizomes may also belong to the group, but until something is known of the seedling structure it is best to omit them from this revision.

\section{The Leaves.}

The leaves in these geophilous species are peltate, except perhaps in the case of $P$. mexicana, though in this species the peltate nature of the lamina is well seen in the aerial cotyledon. The petiole is inserted in a median position, as in $P$. peruviana, $P$. campylotropa, and $P$. bracteata, or more commonly its insertion is at a point at about one-third of the length of the lamina from the base. In outline the lamina may be orbicular, as in two of the species just mentioned, or the apex may be more or less pointed, giving rise to an orbicular-ovate or ovate shape, as in $P$. bracteata, $P$. ovatopeltata, $P$. macrandra, \&c. The lamina is usually flat, but in the smallleaved, xerophytic species of the parvifolia group it is slightly concave.

There is a great difference in the texture of the lamina in the different species, and with this the character of the leaf venation is closely correlated. In $P$. peruviana the lamina is membranous when dry and the veins are very delicate; in a transverse section only a single layer of palisade tissue is seen. Similar membranous leaves are found in $P$. ovato-peltata, claytonioides, macrandra, and gracillima, \&c. Nothing is known of their internal structure, but in these species it is evident from their appearance, and also from information supplied by the collectors, that they live in damp and shady places. A slightly stouter type of leaf, with a well-marked reticulate venation, is found in P. umbilicata, R. and P., and in P. Gaudichaudii. The texture of the lamina in $P$.campylotropa, $P$. monticola, $P$.cyclaminoides, and $P$. rupiceda is of a still firmer nature, being somewhat coriaceous, and the radiating veins can be easily seen, but the internal structure is not known.

The most highly specialized type of lamina is found in the parvifolia group, where it is very much reduced in size and increased in thickness. The small lamina is here usually orbicular-ovate or ovate, peltate about one-third of the distance from the base, and slightly concave. Of the three species concerned, $P$. parvifolia, $P$. verruculosa, and $P$. minuta, the internal structure of the leaf of the first two is known. In a transverse section two or three layers of palisade tissue are seen, below the water-storing tissue on the upper surface of the leaf, an arrangement correlated no doubt with the xerophytic conditions under which these species live.

${ }^{1}$ M. de Candolle tells me that he now considers P. Mülleri and P. Bourgeaui to be the same species and identical with $P$. puberula, Baker. Cf. Hill, l. c., p. $4^{\mathrm{I}} 3$ and footnote. 


\section{THE INFLORESCENCE ${ }^{1}$.}

The inflorescences of these small plants are usually numerous; they develop from the stem-apex and are surrounded by the leaf rosette. They consist of a peduncle bearing the flowers in a spike on its upper part, and may often attain to a considerable length. The lower or barren portion of the peduncle is in most cases about equal in length to the petioles, whilst a great deal of difference is shown in the character of the actual spikes in the different species. They may be short and crowded with flowers-some $5 \mathrm{~mm}$. long in the parvifolia section-or, more commonly, they are long and lax flowered; usually simple, they are frequently branched in P.ovato-peltata and the allied species $P$.claytonioides, $P$. pinulana. The flower is like that found otherwise in the genus, and consists of two stamens and an ovary in the axil of a bract. The bract is peltate, and as a rule appears to be green, though in $P$.ovato-peltata it is white, and may be made use of as a specific character. In shape it is commonly ovate-acute or acuminate, and shows the same texture as the leaves, but in $P$. bracteata it is a fairly large and conspicuous orbicular structure which tends to fold round the spike. The anthers are either almost sessile, or are borne on short filaments $\cdot 4-.6 \mathrm{~mm}$. in length. The fruits are often strikingly different in the different species, and afford the most certain characters for their determination. In most cases they are sessile or subsessile, but in the Central American species $P$. pedicellata, the stalk of the fruit is equal in length to the fruit itself. In shape the fruits are commonly globose or ovoid, and are often very small; they terminate either in a small dome-like style, bearing the stigma at its apex, or the style may be prolonged as in $P$. peruviana, $P$. mexicana, $P$. macrandra, \&c., to form a conical or cylindrical beak, which in the case of $P$. macrandra is equal in length to the berry proper, and bears the stigmatic surface at its apex.

In the case of $P$. rupiced $\alpha$, this stylar portion has extended backwards over the fruit to form a cap, covering the upper half of the globose fruit, and is quite unlike the style of any other geophilous species. The fruitwall also is of a peculiar character, but since no seedlings have been found, it is at present uncertain whether this species really belongs to that subsection of the genus. The fruit-wall throughout the subsection affords some well-marked characters, which are of great value in the determination of the species; they may be arranged in two groups. In the one, the fruit-wall, as seen in surface view, is more or less smooth or slightly reticulated, and appears to be a somewhat delicate structure ${ }^{2}$, whilst in the other, the wall is stouter and more resistant, being more or less deeply pitted, which gives the fruit a verrucose or verruculose appearance. ${ }^{3}$

1 Hill in Ann. Bot. xx, Pl. XXIX, Figs. 1, 2, 27 ; Pl. XXX, Figs. 32, 42.

${ }^{2}$ Cf. Hill, l. c., Pl. XXIX, Fig. 3 .

${ }^{3}$ Ibid. 1. c., Pl. XXIX, Figs. I8, 29。 
To the former type belong $P$. peruviana, $P$. falsa, $P$. Gaudichandii, $P$. ovato-peltata, $P$. claytonoides, and $P$.pedicellata (Pl. XV, Figs. 9 and II), whilst $P$. parvifolia, $P$. vermuculosa, $P$. cyclaminoides, $P$. bracteata, and $P$.campylotropa (Pl. XV, Figs. 16 and I 7$)$ possess the more xerophytic type of fruit characteristic of the second group. The fruit of $P$. monticola (Pl. XV, Fig. I2) is quite distinct from either type, and will be described later.

In all cases the pericarp, which is some three to six cells in breadth, is bounded by a more or less thickened layer of cells, interrupted by pits, and it is these pits which give the surface of the fruit its characteristic appearance. In the group of which $P$. peruviana may be taken as a type, the walls of the external layer of pericarp cells are not much thickened, but the cells of this layer tend to be elongated tangentially, and the pits are broad and shallow. At the base of each pit there is a gland, consisting of a single cell with peculiar refringent contents ${ }^{1}$. The pericarp is usually about three to four cells broad, and the cells contain chlorophyll. When the seed is ripe the cell-walls are often found to have become blackened. The style in this group is usually a somewhat narrow conical or cylindrical organ bearing the stigma at its apex, and in P. mexicana and P. macrandra it attains to a considerable length ${ }^{2}$.

In the xerophytic group, of which $P$.parvifolia is a good example, the pericarp is seen in section to be some five or six cells in breadth; the walls of the outermost layer of cells are more or less strongly thickened, and the cells themselves may be isodiametric or radially elongated ${ }^{3}$.

In some of the species the cells of the outermost layer are more or less isodiametric, as in P. minuta (Pl. XV, Fig. 7), whilst in others they are radially elongated, e.g. $P$. verruculosa ${ }^{4}$ and $P$.cyclaminoides. The innermost layer of cells next the testa is composed of large and tangentially elongated cells in some species. The glands at the base of the pits may be large single cells, as in P. mimuta (Pl. XV, Fig. 7), P. bracteata, P. campylotropa, or they may be composed of a group of four or more cells, as in $P$. parvifolia, $P$. vermuculosa, $P$. cyclaminoides (P1. XV, Fig. I 7 ), where they form conspicuous structures. The style in all these species is a small dome-like button at the apex of the fruit with the stigma at its summit. The fruit of $P$. monticola is peculiar in the black polished and faceted appearance of the surface of the pericarp. In section also it differs from the other geophilous species in the greater development of the pericarp, of which the basal part of the fruit is entirely composed (Pl. XV, Fig. I 2). The outermost layer of the pericarp consists of thick-walled and very regular isodiametric cells, interrupted by narrow and not very deep pits, and this causes the peculiar faceted appearance of the fruit-wall.

1 Hill, l. c., p. 400, Pl. XXIX, Fig. 4.

${ }^{3}$ Ibid., 1. c., p. 405, Pl. XXIX, Figs. 19-20.
2 Ibid., l. c., Pl. XXX, Figs. 43-47.

4 Ibid., l. c., P1. XXIX, Fig. 29. 


\section{SEEDLINGS.}

A few additional facts have come to light about the seedlings of two of the geophilous species. A fairly complete series of young plants of $P$. Gaudichaudii was found amongst Weberbauer's material, and seedlings and young plants of $P$. macrandra-the rhizomatous species-were found in the Boissier and De Lessert Herbaria.

In $P$. Gaudichaudii the development appears to be exactly similar to that described for $P$. pedicellata, although the youngest stages have not been seen. The roots, however, are much more numerous than in that species, and are freely branched, so that with their close felt of root hairs they form a dense mat over the surface of the tiny bulb (P1. XV, Figs. 3 and 4). As the plant gets older the roots are gradually developed in a ring-like manner round the top of the tuber, and so encircle the stemapex. The young seedling of $P$. macrandra has already been described ${ }^{\mathbf{1}}$; the older stages now found are of interest, since they show that the rhizome is formed directly from the plumule by the slow upward growth of the stem-apex, and no curvature of the hypocotyl takes place as in $P$.pedicellata, \&c. (cf. Pl. XV, Fig. I). The figures of the young plants show the radicle at the base of the obovoid tuber with some secondary basal roots, and in the older stage two plumular leaves have developed from between the cotyledons at the apex of the tuber (Fig. 2).

\section{Systematic Arrangement.}

Turning now to the systematic arrangement of the various species, it is clear, in the first place, that they may be separated into two geographical groups, which have no species in common between them, although similar biological adaptations may occur in both areas. The following is a list of the species from the South American and Mexican regions, which, though in some cases imperfectly known, appear to belong to the geophilous subsection of the genus.

\section{South American Species.}

$P$. macrorhiza
$P$. scutellaefolia
$P$. umbilicata
$P$. Gaudichaudii
$P$. peruviana
$P$. falsa

$P$. parvifolia

$P$. verruculosa

P. minuta

P. cyclaminoides

$P$. rupiceda

$P$. cotyledon

${ }^{1}$ Hill in Ann. Bot. xx, p. $4^{12}$, Pl. XXX, Fig. $4^{8}$. 
Mexican and Central American Species.
$P$. ovato-peltata
P. campylotropa
$P$. claytonioides
$P \cdot$ gracillima
P. pinulana
P. mexicana
P. bracteata
P. monticola
$P$. pedicellata
P. macrandra

All the species appear to fall into the section (A.) Eutildenia of Dahlstedt ${ }^{1}$, and they may be regarded as forming a distinct subsection, which for convenience will be termed Geophila.

It is, however, possible that some members of Miquel's subgenus Panicularia $^{2}$, as amplified by Dahlstedt ${ }^{3}$, should be included with the geophilous species, although no evidence has been obtained from seedlings. $P$. cotyledon ${ }^{4}$, particularly, which has a tuberous rhizome and peltate leaves, shows considerable external resemblance to species of the Eutildenia section, and the fruits are also of a similar type. The peculiar character of the compound spike or paniculate inflorescence therefore may have caused a separation of species which are really closely allied.

The position and characters of the subsection are as follows:-

Subgenus V.

Sectio A.

Subsectio I.

\section{Peperomia.}

Tildenia

Eutildenia

Geophila
Miq.

Dahlst.

A. W. Hill.

Tuber hypogaeum vel rhizoma tuberosum. Folia ad caulis basin rosulatim congesta, \pm peltata, glabra. Bractea peltata. Planta novella (germinans) cotyledonibus longiuscule petiolatis heteromorphis; unius brevioris lamina minuta, hypogaea, in semine inclusa, quasi haustorium referens ; alterius lamina parva, peltata, viridis, foliis assimilatoriis similis.

\section{Clavis Specierum.}

A. Tuber hypogaeum basi radicibus instructum. Bacca \pm ovoidea, apice scutulo late conico praedita.

(I) Lamina orbicularis, circa $\mathrm{I} \cdot 5 \mathrm{~cm}$. diametro, coriacea. longa.

T) Parvifoliae.

Amenta 3-4 cm. P. cyclaminoides.

(2) Lamina parva, \pm ovata vel elliptica, carnosula. Amenta $4^{-8} \mathrm{~mm}$. longa.

$\S$ Lamina \pm ovato-orbicularis.

+ Bacca ovato-elliptica, verrucosa.

P. parvifolia.

i† Bacca ovata, valde verruculosa.

$\S \S$ Lamina \pm elliptica, minuta.

Bacca ovato-elliptica, minute punctata.

$P$. verruculosa.

P. minuta.

1 Dahlst. in Kong. Svenska Vet. Akad. Hand. Bd. 33, no. 2, I90o.

${ }^{2}$ Miq., Syst. Pip., p. II 7

3 Dahlst., 1. c., p. 49.

${ }^{4}$ Benth., Pl. Hartweg., in montibus Huacabamba, p. 148 , Hartweg 833 ; cf. also P. umbellata, Miq., Chachapoyas, Peru; Matthews, No. 3230 , Herb. Kew. 
B. Tuber hypogaeum, basi lateribusque radicibus instructum. Bacca apice in appendicem producta.

(I) Lamina suborbicularis, \pm subacuta, sub medium peltata.

P. umbilicata.

(2) Lamina orbicularis, ad medium peltata.

$\S$ Lamina tenuis. Bacca ellipsoidea, apice in appendicem angustam conico-cylindricam producta.

$P$. peruviana.

$\S \S$ Lamina subcoriacea. Bacca globosa, apice in appendicem cylindricam producta.

P. falsa. Species non satis notae.

$\{+$ Lamina ovata, sub medium peltata. $P$. scutellaefolia.

I† Lamina orbicularis, centro peitata. $\quad P$. macrorhiza.

C. Tuber hypogaeum, campylotropum, radicibus fibrosis prope apicem ortis.

If Campylotropae.

(I) Bacca stipitata.

$\S$ Bacca oblongo-cylindrica, stipite baccam ipsam \pm aequante, brevistyla.

$P$. pedicellata.

$\S \S$ Bacca cylindrica, breviter stipitata, longistyla. $\quad P$. mexicana.

(2) Bacca subsessilis.

$\S$ Pedunculus ramosus. Lamina \pm ovata, sub medium peltata.

$P$. ovato-peltata, $P$. claytonioides, $P$. pimulana.

$\S \S$ Pedunculus simplex. Lamina \pm orbicularis.

$\dagger$ Lamina sub medium peltata.

Lamina \pm membranacea, venis conspicue reticulatis. Bractea anguste elliptica, acuminata. Bacca globosoovata, subtiliter reticulata. $\quad P$. Gaudichaudii.

†† Lamina ad medium peltata.

* Lamina tenuis, membranacea. Bractea ovato-acuta.

Stamina filamentis instructa. $\quad P$. gracillima.

** Lamina \pm membranacea. Bractea conspicua, orbicularis.

Stamina filamentis instructa. $\quad P$. bracteata.

*** Lamina coriaceo-membranacea. Bractea ovato-acuminata. Antherae subsessiles.

D. Rhizoma tuberosum, \pm repens.

P. campylotropa.

Tl Rhizomatosae.

(I) Rhizoma repens. Lamina late ovata, acuta. Bacca elliptica, stipitata, in stylum cylindricum baccae aequilongum producta. $P$. macrandra.

(2) Rhizoma exiguum, vel tuber hypogaeum. Lamina ovata, acuminata. Bacca cylindrica, subtiliter stipitata, in stylum cylindricum dimidiam partem baccae aequantem producta.

P. mexicana.

(3) Rhizoma tuberosum. Lamina \pm orbicularis. Bacca nigra, verruculosa, \pm globosa, apice pileo styloso obtecta. P. rupiceda.

(4) Rhizoma vel tuber irregulare. Lamina \pm ovato-rotundata, subacuta. Bacca levis, nigra, cylindrica, apice rotundata; stigma sessilis. 
(5) Rhizoma tuberosum. Lamina \pm orbicularis. Amenta numerosa, in paniculam terminalem longe pedunculatam conferta.

P. cotyledon.

\section{A. Parvifoliae.}

\section{P. cyclaminoides, A. W. Hill, sp. nov. (Pl. XV, Figs. I6 and I7).}

Tuber hypogaeum, globoso-placentiforme more Cyclaminis, $I-2 \mathrm{~cm}$. latum, $\cdot 5^{-1} \mathrm{~cm}$. altum, basi radicibus fibrosis instructum. Caulis subnullus. Folia in rosulam congesta, in sicco luteo-viridia; petiolus $3-7 \mathrm{~cm}$. longus ; lamina orbiculari-ovata, apice obtusa, circa $2 \mathrm{~cm}$. longa, I. $3-1 \cdot 5 \mathrm{~cm}$. lata, coriacea, sub medium ad $\frac{1}{3}$ longitudinis peltata, venis magis minusve distinctis, circa 5. Amenta plura, 3-4 cm. longa, magis minusve laxiflora, pedunculis $6-8 \mathrm{~cm}$. longis. Bractea ovato-acuta, carnosula, circa $\mathbf{I} \cdot \mathbf{I} \mathrm{mm}$. longa, $.7 \mathrm{~mm}$. lata. Stamina filamentis parvis $.4-5 \mathrm{~mm}$. longis instructa. Bacca elliptico-globosa, $\mathbf{I} \cdot 5 \mathrm{~mm}$. longa, I.2 $\mathrm{mm}$. lata, verruculosa, apice scutulo late conico praedita. Semen elliptico-globosum, $.95 \mathrm{~mm}$. longum, $8 \mathrm{~mm}$. latum.

Bolivia Australis. Pinos prope Tarija; 'In steriler feuchter Felswand im Moos,' 2,800 m. Fiebrig, No. 2488 (Herb. Berol.).

P. parvifolia, C. DC.

Tuber hypogaeum, nigrescens, magis minusve globosum, I-I.5 $\mathrm{cm}$. diametro, basi radicibus fibrosis instructum. Caulis subnullus. Folia in rosulam congesta, olivacea; petiolus $1 \cdot 5-2.5 \mathrm{~cm}$. longus; lamina magis minusve triangularis vel suborbicularis, circa $5-7 \mathrm{~mm}$. longa, $5-5.5 \mathrm{~mm}$. lata, apice obtusa vel rotundata, basi rotundata vel subcordata, sub medium ad $\frac{1}{3}$ longitudinis peltata, carnosa, venis haud distinctis. Amenta plura, 4-5 mm. longa, densiflora, pedunculis, petiolis \pm aequilongis. Bractea elliptica, acuta, circa $1 \mathrm{~mm}$. longa, $.6 \mathrm{~mm}$. lata, carnosula. Stamina subsessilia. Bacca \pm ovato-elliptica, fulvo-olivacea, circa $\mathrm{I} \cdot 4 \mathrm{~mm}$. longa, I $\mathrm{mm}$. lata, verrucosa, apice scutulo parvo late conico praedita. Semen ellipticum, circa $.8 \mathrm{~mm}$. longum, $.65 \mathrm{~mm}$. latum.

P. parvifolia, C. DC. in Seeman's Journ. Bot., เ866, p. 133 ; C. DC., in DC. Prod., XVI, i, p. 393 ; Dahlst. in Kong. Svenska Vet. Akad. Hand. Bd. 33, No. 2, 1900, p. 30, Tab. I, Fig. 7. A. W. Hill in Ann. Bot. xx, I906, p. 404, P1. XXIX, Figs. I 8, 27, 28.

Bolivia. Prov. Larecaja. Vic. Sorata, Cabezeras de Chilcani, Lacatia, \&c., 3,600-4,200 m., Mandon, No. II23 (Herb. Kew, Herb. DC., \&c.). Andes of Huanta; I2,000 ft. Pearce (Herb. Kew); Bang. No. I860 -with aborted inflorescences (Herb. Berol.). Copacabana; circa 3:9504,I $20 \mathrm{~m}$. A. $W$. Hill, No. I8I (Herb. Kew). PERU. Herb. Pavon (in Herb. Boiss.). This plant appears to agree with No. I123 of Mandon, but has no ripe fruits.

P. verruculosa, Dahlst., sp. nov.

Tuber hypogaeum, globosum, circa $\mathbf{I} \cdot 2 \mathrm{~cm}$. diametro, basi radicibus 
fibrosis instructum. Caulis subnullus. Folia olivacea, in rosulam congesta; petiolus $\mathrm{I}-2 \mathrm{~cm}$. longus; lamina suborbicularis, apice basique magis minusve rotundata vel basi interdum subcordata, circa $6-8 \mathrm{~mm}$. diametro, paullo sub medium peltata, subcucullata, carnosa, evenia. Amenta plura, 5-8 mm. longa, densiflora, pedunculis petiolis aequilongis. Bractea orbicularis, acuta, circa $\cdot 8 \mathrm{~mm}$. longa, $\cdot 5^{-\cdot 6} \mathrm{~mm}$. lata. Bacca ovata, fusca, circa $\mathrm{I} \cdot 4 \mathrm{~mm}$. longa, I $\mathrm{mm}$. lata, valde et longe verruculosa, apice appendice obscuriore humili mammiformi medio stigmatifera praedita. Semen circa $.8 \mathrm{~mm}$. longum, $.6 \mathrm{~mm}$. latum.

P. verruculosa, Dahlst. ex A. W. Hill, Ann. Bot. xx, 1906, p. 406 (Pl. XXIX, Fig. 29).

Peru. Prope Sachshuaman, Cuzco, 3,700 m. A. W. Hill, no. I 82. (Herb. Kew). Dep. Junin ; inter Tarma et Oroya, 'Kalkfelsen,' 4,000 m. Weberbauer, no. 2544. Ad viam ferream Lima-Oroya, 'Hacienda ArapaYauli' (Porphyrfelsen), 4,400 m. Weberbaner, no. 305 (Herb. Berol.).

P. minuta, A. W. Hill, sp. nov. (Pl. XV, Figs. 6 and 7).

Tuber hypogaeum, depresso-globosum, $8 \mathrm{~mm}$. diametro, $5 \mathrm{~mm}$. altum, basi radicibus fibrosis instructum. Caulis subnullus. Folia olivacea, in rosulam congesta; petiolus $\mathrm{I}-\mathrm{I} \cdot 5 \mathrm{~cm}$. longus; lamina elliptico-orbicularis vel elliptica, 3-3.5 $\mathrm{mm}$. longa, $2-3 \mathrm{~mm}$. lata, subcucullata, sub medium ad $\frac{1}{3}$ longitudinis peltata, carnosa, venis haud distinctis. Amenta plurima, minuta, circa $4 \mathrm{~mm}$. longa, densiflora, pedunculis circa $2 \mathrm{~cm}$. longis. Bractea late elliptica, carnosula, circa $.8 \mathrm{~mm}$. longa, $.6 \mathrm{~mm}$. lata. Stamina subsessilia. Bacca ovato-elliptica, fulva $1.5 \mathrm{~mm}$. longa, $.8 \mathrm{~mm}$. lata, minute punctata vel reticulata, apice scutulo parvo cylindrico praedita. Semen ellipticum, $\cdot 75 \mathrm{~mm}$. longum, $\cdot 6 \mathrm{~mm}$. latum.

Peru. Dep. Ancachs, Prov. Cajatambo ; via inter Ocros et Chonta, cordillera nigra, 4,400 m. Weberbauer, no. 2776 (Herb. Berol.).

I B. Umbilicatae.

P. umbilicata, R. and P.

Tuber hypogaeum, lutescens, globosum vel \pm placentiforme, circa $1.5 \mathrm{~cm}$. diametro, lateribus et praesertim basi radicibus fibrosis instructum, supra nudum. Caulis subnullus. Folia in rosulam congesta, viridia, subtus albida ; petiolus $4^{-6} \mathrm{~cm}$. longus ; lamina magis minusve orbiculata, saepius subacuta, $I \cdot 2-2 \mathrm{~cm}$. diametro, submedium peltata, coriaceo-membranacea, venis reticulatis distinctis. Amenta 6-9 cm. longa, superne densiflora, inferne laxiflora. Bractea ovoideo-orbiculata, circa I mm. longa, $.7-.8 \mathrm{~mm}$. lata. Stamina filamentis instructa. Bacca immatura, \pm conica, $.8-.9 \mathrm{~mm}$. longa, apice in appendicem parvam producta.

P. umbilicata, R. and P., Fl. Peruv., i, p. 30, Tab. 45, Fig. b.

Peru. In Coll. Limae; Chaneay et Huanuci supra saxa, Pavon (Herb. Berol., Herb. Boiss.).

P. peruviana, Miq.; Dahlst. (descr. emend.). 
Tuber hypogaeum, magis minusve globosum, fulvum, subere obtectum, basi lateribusque (ubique) radicibus fibrosis instructum. Caulis subnullus. Folia viridia, in rosulam conferta; petiolus $2-5 \mathrm{~cm}$. longus ; lamina orbicularis, $\mathbf{I}-2 \mathrm{~cm}$. diametro, ad medium peltata, tenuis, in sicco membranacea, venis tenuibus. Amenta $2-5 \mathrm{~cm}$. longa, inferne \pm laxiflora, pedunculis petiolis \pm aequilongis. Bractea ovato-rotundata, circa $\cdot 8-\cdot 9 \mathrm{~mm}$. longa, $\cdot 4-\cdot 5 \mathrm{~mm}$. lata, apice satis longe attenuata. Stamina filamentis instructa. Bacca ellipsoidea, atro-viridis, circa $.7 \mathrm{~mm}$. longa, $.5 \mathrm{~mm}$. lata, minute reticulata, apice in appendicem angustam conico-cylindricam subobliquam circa $\cdot 3 \mathrm{~mm}$. longam summo apice stigmatiferam producta.

P. peruviana, Miq. in Nov. Act. Nat. Cur., no. I9, Suppl., p. 483. Dahlst., 1. c., p. 32, Taf. I, Fig. 9. Hill, in Ann. Bot. xx, I906, p. 400, Pl. XXIX, Figs. I-I 7 .

P. umbilicata, R. and P., 1. c., C. DC., in DC. Prod., XVI, i, p. 393. Dahlst., 1.c., p. $3 \mathrm{I}$.

P. parvifolia, C. DC. (Pentland sp.), in DC. Prodr., XVI, i, p. 393.

Bolivia. S. Francisco de Hay et Pisacoma; Meyen (Herb. Berol.). Prope L. Titicaca, I2,880 ft., Pentland (Herb. Kew). Prov. Larecaja ; Vic. Sorata, collis Ullontigi, 2,800 m., Mandon I,I22 (Herb. Kew, etc.). Guaqui ; $4,000 \mathrm{~m}$. A. W. Hill, no. I 80 (Herb. Kew). Austro-Bolivia; Tucumilla bei Tarija, Fiebrig, no. $2824^{2}$ (Herb. Berol.).

Argentina. Cienega ; Sierra de Tucuman, $8,000 \mathrm{ft}$., no. $65^{8}$, Lorentz et Hieronymus. Prov. Salta ; $\mathrm{N}^{\mathrm{d} 0}$. Castillo, I2,000 ft., Lorentz et Hieronymus (Herb. Berol.). Prov. Salta ; ex pampa grande, 2,800 m., usque ad limina nivis aeternae. Nevado de Cachi, 5,200 m., no. I 2, Speggazini (Herb. DC.).

Forma major.

Petiolus $8-\mathrm{I} 4 \mathrm{~cm}$. longus; lamina orbicularis, $3-3.5 \mathrm{~cm}$. diametro, e medio peltata, membranaceo-coriacea. Amenta circa $8 \mathrm{~cm}$. longa, pedunculis ad $10 \mathrm{~cm}$. longis. Bacca ovato-conica, $\cdot 9 \mathrm{~mm}$. longa, basi $\cdot 5 \mathrm{~mm}$. lata.

Peru. Ollantaytambo; prope Urubamba, $2,500 \mathrm{~m}$. A. W. Hill, no. 183 (Herb. Kew).

P. falsa, sp. nov. A. W. Hill. Pl. XV, Figs. Io and II.

Tuber hypogaeum, irregulariter globosum, circa $\mathrm{I}-2 \mathrm{~cm}$. diametro, basi lateribusque radicibus fibrosis instructum. Folia viridia, in rosulam congesta ; petiolus circa $3-5 \mathrm{~cm}$. longus ; lamina orbicularis, $\mathrm{I}-\mathrm{I} \cdot 3 \mathrm{~cm}$. diametro, subcoriacea, e medio peltata, venis tenuibus. Amenta plurima, $\mathrm{r} \cdot 5-3 \mathrm{~cm}$. longa, \pm densiflora, pedunculis petiolis \pm aequilongis. Bractea orbiculari-acuta, circa $.9 \mathrm{~mm}$. longa. Stamina filamentis minutis instructa. Bacca \pm globosa, circa $.7 \mathrm{~mm}$. longa, $.6 \mathrm{~mm}$. lata, nigra, reticulata, apice in appendicem cylindricam pallide viridem circa $2 \mathrm{~mm}$. longam summo apice stigmatiferam producta.

PERU, Pucara ; inter saxa, 3,700 m. (Puno-Cuzco Via ferrea). Weberbauer, no. 45I (Herb. Berol.). 
P. macrorhiza, Kunth in H. B. and K., Nov. Gen., v. I, p. 72. Dahlst., 1.c., p. 30 .

Peru. Inter Coxamarca et Cerro de Centurcagua, alt. I,8co m. (Herb. Berol.).

The specimen is too meagre to identify; the leaves are small, and the bulb is rather irregular in outline; the inflorescence is immature.

P. scutellaefolia, R. and P., Fl. Per, i, p. 29, Dahlst., 1. c., p. 3 I. PERU. In collibus ad Atiquipa.

\section{9ा C. Campylotropae.}

P. pediceliata, Dahlst. (descr. emend.).

Tuber hypogaeum, parvum, flavum, circa $5 \mathrm{~mm}$. latum, $3 \mathrm{~mm}$. altum, radicibus fibrosis instructum prope apicem ortis. Caulis subnullus. Folia viridia, pauca, in rosulam basalem disposita; petiolus $6-7 \mathrm{~cm}$. longus; lamina ovata vel orbiculari-ovata $2 \cdot 5-3 \mathrm{~cm}$. longa, $2 \mathrm{~cm}$. lata, basi leviter cordata, apice acuta vel \pm acuminata, membranacea, septemnervia, prope basin peltata. Amenta valde laxa, pedunculis tenuibus petiolis longioribus. Bractea ovato-lanceolata, \pm acuminata, circa $I \mathrm{~mm}$. longa. Stamina filamentis instructa. Bacca oblongo-cylindrica, fulva, subtiliter reticulata, longissime stipitata, stipite baccam ipsam \pm aequante, circa $.8-\cdot 9 \mathrm{~mm}$. longa, $\cdot 35 \mathrm{~mm}$. lata, apice appendice conico-cylindrico praedita.

P. pedicellata, Dahlst., 1. c., p. 35, Tab. i, Fig. I3. Hill, 1. c., p. 408, PI. XXX, Fig. 32, \&c.

Guatemala. Santa Rosa; Dept. Santa Rosa, 3,000 ft., F. Donnel Smith, no. $3^{829}$ (Herb. Kew). ${ }^{1}$

P. mexicana, Miq. (descr. emend.).

Tuber hypogaeum, primum parvum, globosum, demum saepius basi lobatum, apice rhizoma exiguum formans, prope apicem radicibus fibrosis instructum. Caulis brevissimus, tuberosus. Folia viridia, in rosulam congesta; petiolus $\mathrm{I} \cdot 5^{-2} \mathrm{~cm}$. longus; lamina ovata, vel ovato-oblonga, acuminata $\cdot 5-2.5 \mathrm{~cm}$. longa, $4 \mathrm{~mm}$. $-\mathrm{I} \mathrm{cm}$. lata, subtrinervia, in sicco membranacea. Amenta 4-5 cm. longa, \pm laxiflora, pedunculis tenuibus circa 4-5 cm. longis. Bractea ovata vel ovato-lanceolata, \pm acuminata, circa I mm. longa. Stamina filamentis instructa. Bacca cylindrica, fulva, circa I $\mathrm{mm}$. longa, $\cdot 3^{-\cdot 4} \mathrm{~mm}$. lata, subtiliter reticulata, breviter stipitata, stylo cylindrico dimidium baccae aequante apice stigmate capitellato terminato.

P. mexicana, Miq., Syst. Pip., p. 75, et in Nov. Act. Nat. Cur., I846, p. 12, Tab. 6. C. DC., in DC. Prodr., XVI, i, p. 394. Dahlst., 1. c., p. 34, Tab. i, Fig. 12. A. W. Hill in Ann. Bot. xx, I906, p. 4I I, Pl. XXX, Figs. $4 \mathrm{I}$ and 42 . 
P. Galleotiana, Hooker, Ic. Pl. iv, Tab. 327.

Tildenia mexicana, Miq. in Diar. Inst. reg. Nederl., 1842.

Mexico. Kickx; Miradores. Linden, no. I27 (Herb. Boiss.). Baranca de St. Francisco prope Mirador ; in rupibus, Liebman, no. 97 (Herb. DC.). Cordillera Vera Cruz; Galeotti, no. 7 I I I (Herb. Kew, Herb. De Less. etc.).

P. ovato-peltata, C. DC. (descr. emend.).

Tuber hypogaeum, globosum, $\mathbf{I}-\mathbf{I} \cdot 8 \mathrm{~cm}$. diametro, radicibus fibrosis confertis instructum, primum ex uno loco prope apicem ortis demum annulum circa rosulam foliorum formantibus. Caulis subnullus. Folia viridia, in rosulam disposita. Petiolus circa 6-I2 cm. longus ; lamina late-ovata, apice acuta, basi rotundata vel subcordata $5-8 \mathrm{~cm}$. longa, $3-5 \mathrm{~cm}$. lata, tenuis, sub medium peltata, venis circa 8 . Scapus $12-18 \mathrm{~cm}$. longus, simplex vel 2-3ramosus, amentis \pm densifloris. Bractea albida, elliptico-acuminata, circa I.5 mm. longa. Stamina filamentis instructa. Bacca immatura, ovatoglobosa, apice stylo conico-cylindrico baccae subaequilongo instructa.

P.ovato-peltata, C. DC. in Seem. Journ. Bot., p. I33, 1866, et in DC. Prod., XVI, i, p. 394; Dahlst., 1.c., p. 34, Tab. i, Fig. 1 I.

P. umbilicata, R. and P., 1.c. Dahlst., 1.c., p. 3 I (F. D. Simith, no. 1430$)$.

Costa Rica. San José ; Hoffman, no. 52 I (Herb. Berol.).

Guatemala. Dep. Baja Verapaz; Sta Rosa inter saxa humida, 5,000 ft. H. von Türckheim, no. I 430 (ed. J. Donnel Smith) (Herb. DC., Herb. Kew). Nova Hispania, Pavon (Herb. Boiss.).

A figure, attributed to this species, is given by Dahlstedt, in which the fruit is ovoid, with a small conical style not unlike that of $P$. parvifolia. The fruits of the specimens at Berlin are not quite ripe, but they are more or less globose with a fairly long cylindrical style, and appear to agree with those of $P$.claytonioides. It seems therefore probable that there is some mistake about Dahlstedt's figure.

P. pinulana, C. DC. (descr. emend.).

Tuber hypogaeum, placentiformi-globosum, circa $6 \mathrm{~mm}$. latum, $4 \mathrm{~mm}$. altum, radicibus fibrosis instructum, ex uno loco prope apicem ortis. Folia obscure viridia; petiolus circa $77 \mathrm{~cm}$. longus ; lamina subovato-rotundata, circa $3 \mathrm{~cm}$. diametro, apice breviter obtusiuscule acuminata, basi repandocordulata, carnosa, in sicco tenuissime membranacea, pellucida, $\frac{1}{3}$ supra basin peltata, venis 9. Scapus ramosus, foliis circiter aequilongus; amenta cum pedunculis $(\mathrm{I} \mathrm{cm}$.) circa $3 \mathrm{~cm}$. longa. Bractea subovato-elliptica, apice subulata. Bacca ovata, apice in stylum contracta, stylo apice imo stigma globulosum puberulum gerens.

P. pimulana, C. DC. in Engl., Bot. Jahrb. x, p. 289.

Guatemala. Supra Pinula; prope Xalapa, ad truncos arborum in silvis; $1,800 \mathrm{~m}$. Lehmann, no. 1693 (Herb. Boiss.). ${ }^{1}$ 
P. claytonioides, Kunth (Pl. XV, Figs. 8 and 9).

Tuber hypogaeum, globosum, circa $7 \mathrm{~mm}$. diametro, radicibus fibrosis ex uno loco prope apicem instructum. Caulis subnullus. Folia supra laete viridia, subtus glaucescenti-viridia, opaca, in rosulam congesta. Lamina orbicularis vel ovato-orbicularis, $3-4 \mathrm{~cm}$. diametro, apice acutiuscula, sub medium peltata, carnosula, venis 6-8. Scapus simplex vel 2-3 ramosus, ad $30 \mathrm{~cm}$. longus; amenta laxiflora. Bractea ovato-acuminata, carnosula, centro viridula, ceterum albida, supra basin rotundata. Stamina filamentis instructa. Bacca globosa, $.8 \mathrm{~mm}$. diametro, rugosa, apice in appendicem angustam cylindricam circa $4 \mathrm{~mm}$. longam summo apice stigmatiferam producta. Semen globosum, $.65 \mathrm{~mm}$. diametro.

P. claytonioides, Kunth in Ind. Sem. Hort. Bot. Berol., I847, p. II. C.DC. in DC. Prodr., XVI, i, p. 400. Dahlst., 1.c., p. 33, Tab. i, Fig. Io.

Guatemala. Loco non indicato. Sauer communic. Specimina culta. H. Lefr. Montp. (Herb. Berol.). Ex Hort. Berol. (I847), (Herb. Berol.). Ex Hort. Kew, I 863 (Herb. Kew).

$P$. claytonioides is of considerable interest, since it appears to be the only geophilous species which has been raised from seed in Europe. In fact all of the specimens in our herbaria have been grown in different botanical gardens, and the original description of the species was founded on a plant raised in the gardens at Berlin. This species is very closely allied to $P$. ovato-peltata, as Dahlstedt ${ }^{1}$ has already pointed out. It may, indeed, be identical with it, and possibly represents the cultivated form of $P$. ovato-peltata. In the shape of the leaves, the white inflorescence bracts and the fruits, which are globose with a style $\cdot 3^{-\cdot 4} \mathrm{~mm}$. long, this species seems to agree with $P$. ovato-peltata. The most important points of difference are seen in the much larger and more delicate leaves of $P$.ovato-peltata, coupled with inflorescences which are shorter and less branched than those of $P$.claytonioides, both of which characters must be considerably influenced by environment.

$P$. pimulana is closely allied to both $P$. ovato-peltata and $P$. claytonioides, and Dahlstedt suggests that it may be only a variety of the latter. It seems to me more likely that both these species should be united to $P$. ovato-peltata, but the material is at present too scanty to justify such a union.

P. Gaudichaudii, A. W. Hill, sp. nov.

Tuber hypogaeum, parvum, globosum, $\cdot 5^{-\mathrm{I} \cdot 2} \mathrm{~cm}$. latum, 4-6 m. altum, radicibus fibrosis instructum, primum ex uno loco prope apicem ortis deinde rosulam foliorum cingentibus tuber obscurantibus. Caulis subnullus. Folia in rosulam congesta, olivacea ; petiolus $2-8 \mathrm{~cm}$. longus ; lamina triangulariorbicularis vel cordato-orbicularis, apice subobtusa, circa 5-9 $\mathrm{mm}$. longa, 6-8 $\mathrm{mm}$. lata, magis minusve membranacea, sub medium peltata, venis 
conspicue reticulatis. Amenta pauca, laxiflora, $6-8 \mathrm{~cm}$. longa, pedunculis 2-6 cm. longis. Bractea anguste elliptica, acuminata, circa I $\mathrm{mm}$. longa, $.4 \mathrm{~mm}$. lata. Stamina filamentis instructa. Bacca globoso-ovata, circa $1 \mathrm{~mm}$. longa, $.8 \mathrm{~mm}$. lata, subtiliter reticulata, atrofusca. Semen $\cdot 75 \mathrm{~mm}$. longum, .65 latum.

P. umbilicata, R. and P., 1.c. Miq., Syst. Pip., p. 7o. C. DC. in DC, Prod, XVI, i, p. 393. Dahlst., l.c., p. 3I.

$P$. peruviana, Dahlst., l.c., p. 33 (in parte).

PERU. Callao prope Lima, Gaudich. (Herb. Berol.). Lima, Gaudich. no. I50 (1834) (Herb. Berol., Herb. DC.). San Lorenzo, Lima, Callao, Gaudich. (Voyage Bonite, I836). San Lorenzo, Gaudich., no. I5o (1832) (Herb. De Less.). Lima, Dombey, Boivin (1 839) (Herb. Boiss.). Amancaës ; in montibus prope Lima, saxa in 'Loma formation' 200-800 m., Weberbaner, no. I6 32 (Herb. Berol.). Dept. Junin, Prov. Tarma; Huacapitana ad Palca, I900-2000 m. Weberbauer, no. $2013^{1}$ (Herb. Berol.).

P. gracillima, S. Watson (descr. emend.).

Tuber hypogaeum, parvum, globosum, radicibus fibrosis instructum, prope apicem ortis. Caulis subnullus. Folia facie viridia, in dorso cuprea, in rosulam conferta; lamina magis minusve orbicularis, circa $1 \cdot 5-2 \mathrm{~cm}$. diametro, ad medium peltata, tenuis. Amenta cum pedunculis filiformibus circa $10 \mathrm{~cm}$. longa. Stamina filamentis circa $.6 \mathrm{~mm}$. longis instructa. Bacca immatura.

P. gracillima, S. Watson in Proc. Amer. Acad., xxii. (N. S., xiv), 1887 , p. 448 .

Mexico. State of Jalisco; Rio Blanca, Palmer, no. $5^{8} 5$ (Herb. Kew), in deep recesses of overhanging rocks.

Though the material is imperfect, this seems to be a distinct species, differing from $P$. campylotropa in the delicate membranous leaves and the stalked anthers.

P. bracteata, A. W. Hill, sp. nov. (Pl. XV, Fig. I 5).

Tuber hypogaeum, orbiculare, circa $\cdot 8-\mathrm{I} \cdot 2 \mathrm{~cm}$. diametro, apice radicibus fibrosis instructum. Caulis subnullus. Folia viridia, in rosulam congesta ; petiolus $8-10 \mathrm{~cm}$. longus; lamina rhomboideo-orbicularis vel orbicularis, apice saepius paullo obtusa, $2-3 \mathrm{~cm}$. diametro, fere e medio peltata, magis minusve membranacea, venis $8-9$ conspicuis. Amenta $5^{-20} \mathrm{~cm}$. longa, inferne laxiflora, pedunculis circa $10 \mathrm{~cm}$. longis. Bractea viridis, magis minusve orbicularis, circa $1.5 \mathrm{~mm}$. diametro; stamina filamentis instructa. Bacca globoso-fusiformis, $\mathrm{I} \cdot 5 \mathrm{~mm}$. longa, $\cdot 95 \mathrm{~mm}$. lata, verrucosa, fulva, apice stylo cylindrico-conico praedita. Semen ellipticum, circa I mm. longum, $\cdot 8 \mathrm{~mm}$. latum.

1 This specimen probably belongs to this species, but the material is insufficient for a complete determination. 
Guatemala. Dep. Huehuetenango; Sactos, inter saxa, Caec. et Ed. Seler, no. 273I. 'Estancia de la Virgen' ad imam arborum, ibid., no. 274.3 (Herb. Berol.).

P. campylctropa, A. W. Hill, sp. nov.

Tuber hypogaeum, placentiformi-globosum, circa $I-2 \mathrm{~cm}$. latum, $.8-\mathrm{I} \cdot 2 \mathrm{~cm}$. altum, radicibus fibrosis instructum, ex uno loco prope apicem ortis. Caulis subnullus. Folia viridia in rosulam disposita; petiolus $3-8 \mathrm{~cm}$. vel saepius $15-20 \mathrm{~cm}$. longus ; lamina suborbicularis, $\mathrm{I} \cdot 5-3 \cdot 5 \mathrm{~cm}$. diametro, e medio peltata, magis minusve membranacea vel coriaceo-membranacea, venis 6-9 inferne distinctis. Amenta \pm densiflora, cum pedunculis 8-20 vel interdum $30 \mathrm{~cm}$. longa. Bractea ovata, acuminata, circa $1 \cdot 5^{-1 \cdot 7} \mathrm{~cm}$. longa, $\cdot 8-.9 \mathrm{~cm}$. lata. Stamina subsessilia. Bacca globoso-ovata, atro-fusca, circa $\mathbf{I} \cdot 7 \mathrm{~mm}$. longa, I.2 $\mathrm{mm}$. lata, verrucosa, apice scutulo late conico praedita. Semen globoso-ellipticum $\cdot 96 \mathrm{~mm}$. longum, $.86 \mathrm{~mm}$. latum.

P. umbilicata, Kunth in H. B. and K. Nov. Gen., I, p. 59, Pl. XV, Fig. I. Hill, in Ann. Bot., xx, I906, p. 407. Pl. XXX, Fig. 31 .

P. umbilicata, R. and P., l.c. Miq., Syst. Pip., p. 7o. C. DC. in DC. Prod., XVI, i, p. 393. Dahlst., l.c., p. 31.

P. umbilicata, var. macrophylla, C. DC. in DC. Prod., XVI, i, p. 394.

Mexico. In locis excelsis scopulosis frigidis regni Mexicani, prope Sta. Rosa de la Sierra et Los Ioares alt. 2,600 m. Humboldt (Herb. Berol.) ; Humboldt, no. 764 (Herb. Willd.); Uhde, no. 253 (Herb. Berol.). Pédrégal; Vallée de Mexico 'among damp rocks with Ferns,' Bourgeau, no. 418. Santa Fé; Vallée de Mexico, Bourgeau, no. 63I (Herb. Kew, Herb. Boiss., Herb. DC.). State of Michoacan; 'damp hillsides' prope L. Patzcuaro, Pringle, no. 4I 24 (Herb. Kew, Herb. Boiss., Herb. Berol.). San Luis Potosi; $22^{\circ}$ N. 6,0c0-8,000 ft., no. 802, Parry and Palmer (Herb. Kew, Herb. Boiss.)

P. sp. dubia ; Mexico. Graham, I83o (Herb. Kew). Mexico; Zunapan, Coulter, no. I 399 (Herb. Kew).

The plants included in this species differ considerably in the external morphology of their leaves. In the specimens collected by Pringle the leaf lamina is delicate, whilst in the Parry and Palmer specimens, \&c., the lamina is fairly stout and rather coriaceous. In the characters of the bract, stamens, and fruit, however, there seems to be a fairly close agreement, so that the differences in general habit are probably due to the nature of the situations from which the various specimens have been collected.

I. Rhizomatosae.

P. macrandra, C. DC. (descr. emend.).

Rhizoma hypogaeum, repens, circa $3 \mathrm{~cm}$. longum, nigrum, ramis \pm erectis circa $\mathrm{I} \mathrm{cm}$. longis, radicibus fibrosis instructum. Folia viridia ; petiolus $10-15 \mathrm{~cm}$. longus; lamina late ovata, acuta, $6-7 \mathrm{~cm}$. longa, 
4-4.5 cm. lata, $\frac{1}{6}$ supra basin peltata, in sicco membranacea, venis $5^{-7}$. Amenta ad $13 \mathrm{~cm}$. longa, inferne laxiflora, pedunculis ad $7 \mathrm{~cm}$. longis. Bractea ovata, apice acuminata, fere e medio peltata. Stamina filamentis, circa $\mathrm{I} \cdot 5 \mathrm{~mm}$. longis instructa. Bacca elliptica, circa $\mathrm{I} \cdot 2 \mathrm{~mm}$. longa, breviter $(\cdot 4 \mathrm{~mm}$.) stipitata, in stylum cylindricum baccae aequilongum producta, summo apice stigma minute puberulum gerens.

P. macrandra, C. DC. in Ann. du Conserv. du Jard. Bot. Genève, 1898, p. 276 . Hill, in Ann. Bot., xx, 1906, p. 412. Pl. XXX, Fig. 46.

Mexico. Prov. Oaxaca; Sierra de San Felipe, 'wet ledges,' 8,500 ft. Pringle, no. 4654 (Herb. De Less., Boiss., Kew, Brit. Mus.).

P. monticola, Miq. (descr. emend.) (Pl. XV, Fig. 12).

Tuber hypogaeum, irregulariter globosum, vel rhizoma tuberosum, 2-4 $\mathrm{cm}$. longum, circa $\mathrm{I}-5 \mathrm{~cm}$. diametro, supra saepius ubique radicibus fibrosis instructum. Caulis brevissimus vel subnullus. Folia atro-viridia, in rosulam congesta; petiolus $6-12 \mathrm{~cm}$. longus; lamina rhomboideorotundata vel rotundo-ovata, apice subacuta, basi subcordata, circa $3-4.5 \mathrm{~cm}$. diametro, e medio peltata, magis minusve coriacea, venis 7-9 conspicuis Amenta crassiuscula, \pm densiflora, cum pedunculis $10-20 \mathrm{~cm}$. longa. Bractea ovata, acuta, $.7 \mathrm{~mm}$. longa. Stamina subsessilia. Bacca nigra, cylindrica, facie nitens, tessellata, circa $1.9 \mathrm{~mm}$. longa, $1 \mathrm{~mm}$. lata, apice basique rotundata, apice stigmate sessili praedita.

P. monticola, Miq. Syst. Pip., p. 7I. Benth. in Pl. Hartweg, p. 293. Dahlst., 1.c., p. 32 .

P. umbilicata, $\beta$. subacutifolia, C. DC. in DC. Prod., XVI, i, p. 394.

P. umbilicata, a. macrophylla, C. DC. 1. c.

Mexico. Galeotti, no. 6023 (Herb. De Less.). Aguas Calientes ; Hartweg, no. 1621 (Herb. Kew, Herb. De Less.); Uhde, no. 254 (Herb. Berol.). San Luis Potosi ; Schaffner, no. 633 (Herb. Berol. ex Herb. Vigener). Convalli San Luis Potosi ; in locis humidis, Schaffner no. Io8 (Herb. Kew).

P. cotyledon, Benth. Pl. Hartweg, p. 148. C. DC. in DC. Prod., XVI, i, p. 40 I. Dahlst., 1.c., p. 53 .

PERU vel Ecuador. Huacabamba; in montibus, Hartweg, no. 833 (Herb. Kew, \&c.).

Rhizome tuberous, peltate radical leaves. Inflorescence terminating in a short dense compound spike, with one or two whorls of leaves on the peduncle.

P. rupiceda, C. DC., MS. (sp. nov.) (Pl. XV, Figs. I3 and 14).

Peru. Lima. Oroya ; inter Matucama et Tambo de Visa, 2,3702,650 m. Weberbauer, no. I 45 (Herb. Berol.). 


\section{Geographical Distribution.}

The geophilous species form a very natural biological group, and their respective habitats seem to be fairly well defined. Too great stress must not be laid in all cases on the underground tuber as a guide to the relationships of different species, since the external features of any of thcse plants appear to depend largely on the conditions of their particular habitats. The parvifolia group, however, does seem to be a very natural one, for not only do the several species show affinities in numerous points, but they occur in a fairly definite line from about $10^{\circ}-18^{\circ} \mathrm{S}$. latitude. $P$. minuta is the most northerly species, and is succeeded by $P$. vermculosa in the regions from Oroya to Cuzco; $P$. parvifolia occurs around the southern end of Lake Titicaca, and P.cyclaminoides, which perhaps is not so closely related to the other three species, has been found in the mountains of Southern Bolivia near Tarija. They all show well-marked xerophytic characters, and apparently live in exposed places. Under such conditions the roots from the base of the bulb, growing more or less vertically downwards, would be able to obtain water from soil at some depth below the quickly drying surface.

The other South American species are more distinctly shade plants, with a fairly large leaf lamina, thin and membranous in texture when dried, and the walls of their fruits are delicate and apparently contain chlorophyll. Of the four well-known species of that group, $P$. umbilicata, $P$. peruviana, and $P$. falsa are no doubt closely allied. Their bulbs, with lateral and horizontally running adventitious roots, are similar in character. P. Gaudichandii, however, in its campylotropous bulb, is a very distinct form, though in other respects it shows fairly close relationship to $P$. umbilicata. With the Mexican campylotropous species $P$. Gaudichaudii appears to have only a biological connexion, since it differs from them both in leaf and floral characters, and it seems most likely that a similar biological adaptation has arisen independently in the two widely separated localities.

Of the species just mentioned, $P$. peruviana appears to have the most extended range, namely from the vicinity of Urubamba in Peru in the north to the south of Bolivia, and to the province of Salta in the Argentine, whilst $P$. Gaudichaudii appears to be restricted to relatively low country $(200-800 \mathrm{~m} .)^{1}$ in the neighbourhood of Lima.

The Central American and Mexican species are recorded from Costa Rica ( $P$. ovato-peltata), Guatemala ( $P$. claytonioides, $P$. pinulana, $P$. pedicellata, $P$. bracteata), and from Mexico to about as far north as lat. $22^{\circ} \mathrm{N}$. $P$. monticola, from the region of S. Luis Potosi, is the most northerly

1 Weberbaner's No. 2013 from the Province of Tarma, Dept. Junin, I900-2000 m. in the mountains above Lima, may perhaps belong to this species. 


\section{Hill.-A Revision of the Geophilous Species of Peperomict. 159}

species. $P$. campylotropa and $P$. gracillima occur on the Pacific side of Mexico, whilst $P$. mexicana is found on the Atlantic side of the country in the Cordillera of Vera Cruz. P. macrandra from the province of Oaxaca appears to be the most southerly of the Mexican species.

All the species seem to be somewhat definitely localized, and with the exception of $P$. monticola, and perhaps some specimens referred to $P$. campylotropa, are all distinctly shade-loving plants. $P$. bractcata, and $P$. campylotropa to a much slighter degree, show some xerophytic characters in their verrucose fruits, but the leaves in these species are thin and membranous, and in some (e. g. P. gracillima) are very delicate.

The various species are in nearly all cases easily recognized and sharply defined, the bulbous habit and seedling structure being the principal points of similarity. $P$. pedicellata, $P$. mexicana, and $P$. macrandra show some affinity judging from their fruits and leaves, and $P$. ovato-peltata, $P$. claytonioides and $P$. pimulana form a very natural group, or perhaps they are only slightly different forms of the same species.

Of the remaining species there is little to be said. $P$. monticola is a very distinct form, and perhaps should not be included in this group. Of $P$. campylotropa and $P$. gracillima we have not sufficient material to point out their relationships.

Four new species of these geophilous Peperomias have been found in the last two or three years, and a careful examination of material, which has lain in Herbaria for many years, has revealed three or four distinct species hitherto confused with species already described. It seems, therefore, highly probable that there may be several species, as yet unknown to science, in the mountains of Central and South America, and a knowledge of their biological characters, seedling structure, and conditions of life would doubtless yield results of the highest interest.

\section{EXPLANATIONS OF FIGURES IN PLATE XV.}

Illustrating Mr. A. W. Hill's Paper on Peperomia.

The sections of the fruits are from photographs.

Fig. I. P. macrandra, C. DC., a young seedling showing the laminae of both cotyledons and the tuber. $\quad c_{1}=$ absorbent, $c_{2}=$ assimilating cotyledon.

Fig. 2. An older plant. Two plumular leaves have developed and the tuher has enlarged.

Fig. 3. P. Gaudichaudii, a young seedling, with its seed. The tuber is obscured by the closely felted roots.

Fig. 4. An older tuber seen from above, showing the two cotyledon scars and the point of emergence of the roots. 
Fig. 5. P. mexicana, showing the development of the rhizome. The petiole bases only are shown. Fig. 6. P. minuta, the fruit. $\times 9$.

Fig. 7. The same in section. $\times 35$.

Fig. 8. P. claytonioides, the fruit. $\times$ I0.

Fig. 9. The same in section. $\times 4^{\circ}$.

Fig. 10. P. falsa, the fruit. $\times$ 10.

Fig. I1. The same in section. $\times 40$.

Fig. I2. P. monticola, the fruit in section. $\times 4^{\circ}$.

Fig. 13. P. rupiceda, the fruit. $\times 9$.

Fig. 14. The same in section. $\times 35$.

Fig. 15. P. bracteata, the fruit. $\times 10$.

Fig. 16. P. cyclaminoides, the fruit. $\times 9$.

Fig. 17. The same in section. $\times 45$. 
Annals of Botany.
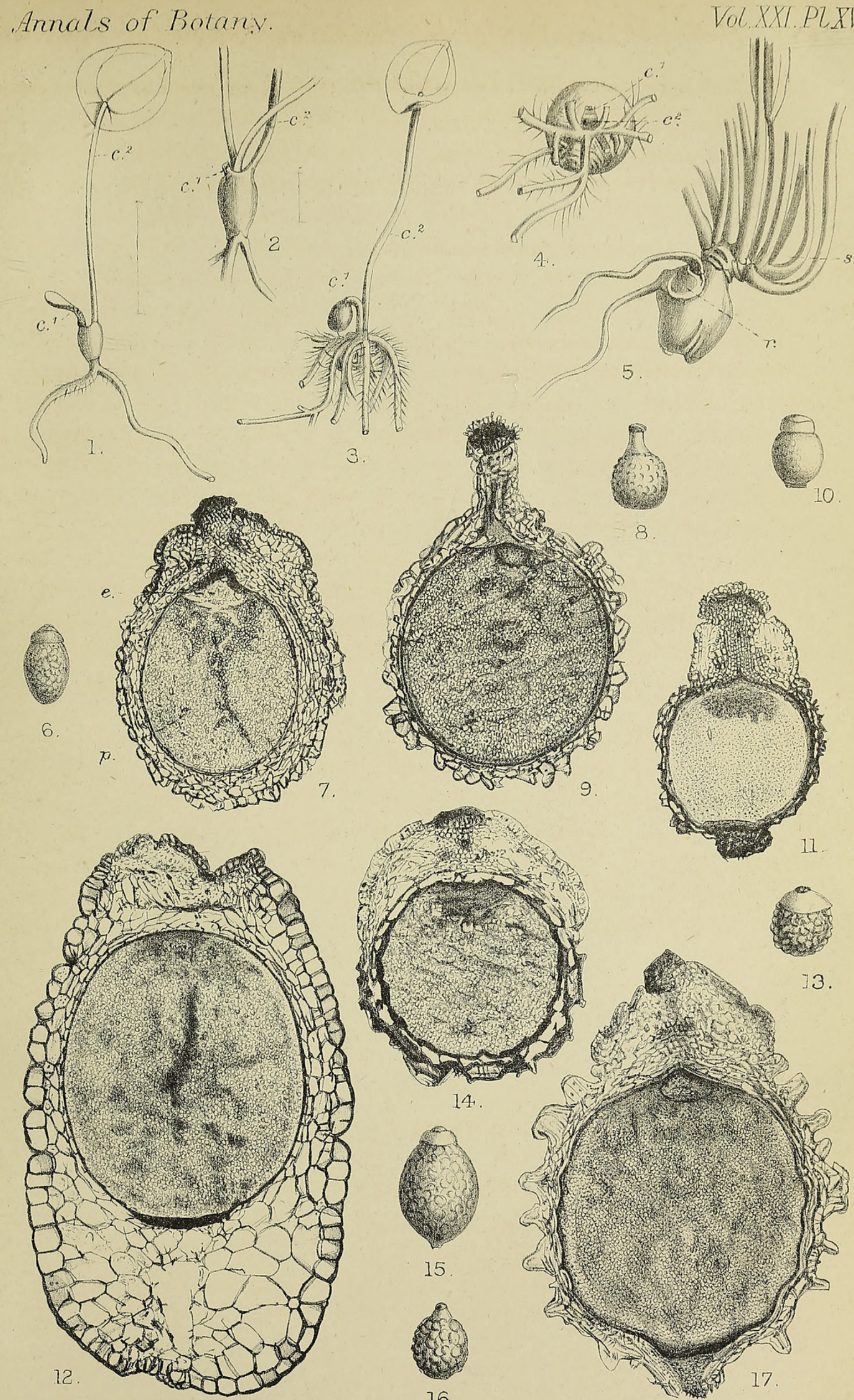

A.W.H. del.

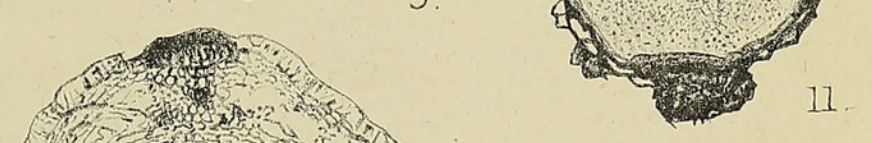

W.Tams phot.

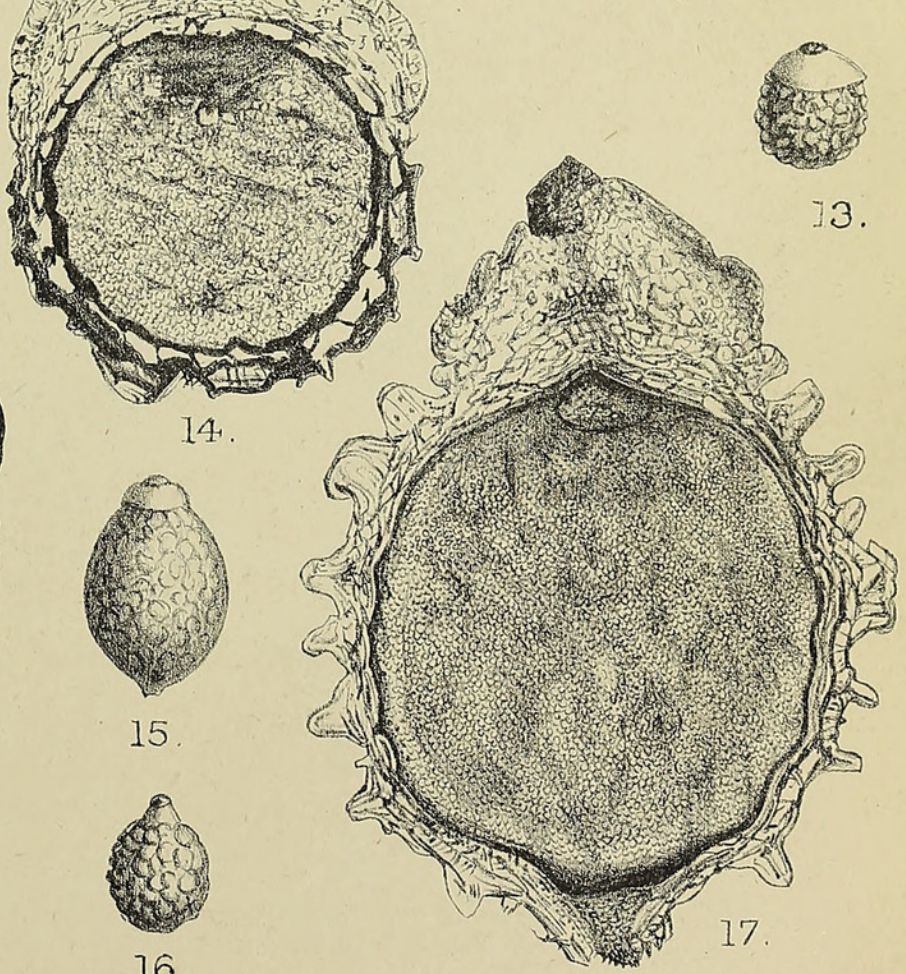

Huth lith et imp.

HILL - PEPEROMIA. 


\section{$2 \mathrm{BHL}$ Biodiversity Heritage Library}

Hill, Arthur William. 1907. "A revision of the geophilous species of Peperomia, with some additional notes on their morphology and seedling structure." Annals of botany 21, 139-160.

https://doi.org/10.1093/oxfordjournals.aob.a089128.

View This Item Online: https://www.biodiversitylibrary.org/item/235747

DOI: https://doi.org/10.1093/oxfordjournals.aob.a089128

Permalink: https://www.biodiversitylibrary.org/partpdf/318867

\section{Holding Institution}

Smithsonian Libraries

\section{Sponsored by}

Biodiversity Heritage Library

\section{Copyright \& Reuse}

Copyright Status: Not in copyright. The BHL knows of no copyright restrictions on this item.

This document was created from content at the Biodiversity Heritage Library, the world's largest open access digital library for biodiversity literature and archives. Visit BHL at https://www.biodiversitylibrary.org. 